\title{
Biochemical Neutralization of Coke Excess Sewage Sludge During Anaerobic Digestion Process
}

\author{
B. Macherzyński ${ }^{a, *}$ and M. Włodarczyk-Makuła \\ ${ }^{a}$ Faculty of Biology and Environmental Science, \\ Cardinal Stefan Wyszynski University in Warsaw, \\ Wóycickiego 1/3, 01-938 Warsaw, Poland \\ ${ }^{b}$ Faculty of Infrastructure and Environment, \\ Częstochowa University of Technology, \\ Dąbrowskiego 69, 42-201 Częstochowa, Poland
}

doi: 10.15255/CABEQ.2016.1041

Original scientific paper Received: November 23, 2016 Accepted: May 28, 2018

The paper presents the results of the study concerning the production of biogas, thermal energy gain and changes of physical-chemical properties during the process of anaerobic digestion of the municipal sewage sludge amended with coke sewage sludge. The control sample $(\mathrm{K})$ consisted of primary, excessive, and digested sewage sludge (municipal sewage sludge). Another sample consisted of sample (K) and coke sewage sludge $(20: 1 \mathrm{v} / \mathrm{v})$. The total volume of biogas was equal to $0.62 \mathrm{~L} \mathrm{~g}^{-1} \mathrm{TS}$ and $0.56 \mathrm{~L} \mathrm{~g}^{-1}$ TS during the anaerobic digestion of the municipal sewage sludge and during the digestion of the mixture of the municipal sludge and the coke sewage sludge, respectively. The gain of the thermal energy of methane was $40 \%$ during the digestion process. The percentage of decomposition of the organic substance was similar in municipal sewage sludge and in the mixture of municipal sewage sludge amended with coke sewage sludge.

Keywords:

anaerobic digestion, coke sewage sludge, municipal sewage sludge, biogas, methane, thermal energy gain

\section{Introduction}

During the process of waste treatment, sewage sludge is formed with various qualitative and quantitative compositions. The quality of sewage sludge depends on the characteristics of the sewage, and the form and techniques of the treatment. The sewage sludge is a heterogeneous material. The process of computation and neutralization of the sewage sludge is one of the major issues of wastewater management both for the municipal and industrial sewage treatment plants. The wastewater in the coking plant is treated using biological processes. The sewage sludge formed during treatment process is polluted with the following contaminants: phenols, tar and oily substances, aliphatic and aromatic hydrocarbons, organic and inorganic halogenated compounds, ammonia, cyanides, hydrogen sulphide, thiosulfates, sulphates and chlorides ${ }^{1-4}$. Thus, the effectiveness of decomposition of these pollutants is required.

The treatment of municipal sewage sludge is carried out in the following processes: biological stabilization under aerobic condition, anaerobic digestion, dewatering and drying.

"Corresponding author: b.macherzynski@uksw.edu.pl
In anaerobic digestion, the decomposition of organic substances produces a biogas, the main components of which are methane and carbon dioxide. The biogas also consists of nitrogen, oxygen, hydrogen, hydrogen sulphide, carbon oxide, ammonia, and other gases in minor quantities, respectively ${ }^{5-10}$. Table 1 shows the biogas components produced during anaerobic digestion of the sewage sludge.

There is a possibility of energy recovery during the digestion of sludge. The produced biogas can be applied for heating digestion chambers and the production of electrical energy. Before using the biogas, it is necessary to remove the hydrogen sulphide and water steam that causes corrosion and contributes to shorter operating time of the power equipment. The biogas is processed into thermal energy in boilers, electrical energy in gaseous current generators, and electrical and thermal energy in combined systems. In the anaerobic stabilization, the quantity of methane and carbon dioxide in the biogas depends on the composition of the substrate.

Methanogens are absolute anaerobes belonging to Archaeobacteriales that use hydrogen as a source of energy and carbon dioxide as a source of carbon. During methanogenesis, methane is produced from the acetic acid according to the reaction given below $(1)^{20}$ : 


$$
\mathrm{CH}_{3} \mathrm{COOH} \rightarrow \mathrm{CH}_{4}+\mathrm{CO}_{2}
$$

The other quantity of methane, that is about 30 $\%$, is produced as a result of the reaction of carbon dioxide and hydrogen - reaction (2):

$$
4 \mathrm{H}_{2}+\mathrm{CO}_{2} \rightarrow \mathrm{CH}_{4}+2 \mathrm{H}_{2} \mathrm{O}
$$

Methane can also be formed from formats, methanol, carbon dioxide, trimethylamines, dimethylamines, methylamines, dimethyl sulphide and metal ions $(3-10)$ :

$$
\begin{gathered}
4 \mathrm{HCOOH} \rightarrow \mathrm{CH}_{4}+\mathrm{CO}_{2}+2 \mathrm{H}_{2} \mathrm{O} \\
4 \mathrm{CH}_{3} \mathrm{OH} \rightarrow 3 \mathrm{CH}_{4}+\mathrm{CO}_{2}+2 \mathrm{H}_{2} \mathrm{O} \\
4 \mathrm{CO}+2 \mathrm{H}_{2} \mathrm{O} \rightarrow \mathrm{CH}_{4}+3 \mathrm{H}_{2} \mathrm{CO}_{3} \\
4\left(\mathrm{CH}_{3}\right)_{3} \mathrm{~N}+6 \mathrm{H}_{2} \mathrm{O} \rightarrow 9 \mathrm{CH}_{4}+3 \mathrm{CO}_{2}+4 \mathrm{NH}_{3} \\
2\left(\mathrm{CH}_{3}\right)_{2} \mathrm{NH}+2 \mathrm{H}_{2} \mathrm{O} \rightarrow 3 \mathrm{CH}_{4}+\mathrm{CO}_{2}+2 \mathrm{NH}_{3} \\
4\left(\mathrm{CH}_{3}\right)_{\mathrm{NH}_{2}}+2 \mathrm{H}_{2} \mathrm{O} \rightarrow 3 \mathrm{CH}_{4}+\mathrm{CO}_{2}+4 \mathrm{NH}_{3} \\
2\left(\mathrm{CH}_{3}\right)_{2} \mathrm{~S}+2 \mathrm{H}_{2} \mathrm{O} \rightarrow 3 \mathrm{CH}_{4}+\mathrm{CO}_{2}+2 \mathrm{H}_{2} \mathrm{~S} \\
4 \mathrm{Me}^{0}+8 \mathrm{H}^{+}+\mathrm{CO}_{2} \rightarrow 4 \mathrm{Me}^{++}+\mathrm{CH}_{4}+2 \mathrm{H}_{2} \mathrm{O}
\end{gathered}
$$

Anaerobic digestion is a labile process affected by both the compounds introduced with the sludge (external), and the products formed as a result of transformations of the organic compounds during the process (internal) ${ }^{21}$. The toxic compounds that

\begin{tabular}{|c|c|c|c|c|c|}
\hline Gas & $\begin{array}{c}\text { Percentage, } \\
\%\end{array}$ & Reference & Gas & $\begin{array}{c}\text { Percentage, } \\
\%\end{array}$ & Reference \\
\hline \multirow{7}{*}{$\mathrm{CH}_{4}$} & 63 & 11 & \multirow{2}{*}{$\mathrm{H}_{2} \mathrm{~S}$} & $0.1-0.5$ & 18 \\
\hline & $65-71$ & 12 & & $0-1$ & 19 \\
\hline & $51-72$ & 13 & \multirow{2}{*}{$\mathrm{CO}$} & $0.1-0.5$ & 18 \\
\hline & 65 & 14 & & $0-2$ & 19 \\
\hline & 66 & 15 & $\mathrm{H}_{2}$ & $1-3$ & 18 \\
\hline & $33-70$ & \multirow[t]{2}{*}{16} & $\mathrm{H}_{2} \mathrm{O}$ & $2-7$ & 19 \\
\hline & $71-72$ & & \multirow{2}{*}{$\mathrm{O}_{2}$} & $0-2$ & 19 \\
\hline \multirow{2}{*}{$\mathrm{CO}_{2}$} & $26-32$ & 16 & & $0.1-1$ & 18 \\
\hline & $25-40$ & 18 & \multirow{2}{*}{$\mathrm{N}_{2}$} & $0-2$ & 18 \\
\hline $\mathrm{NH}_{3}$ & $0-1$ & 19 & & $0.5-2.5$ & 18 \\
\hline
\end{tabular}
are introduced with the sewage sludge and can show inhibitory action include organic substances and mineral substances, oxygen, heavy metals and pesticides $^{22,23}$. The intermediate products that are formed during the process of anaerobic digestion are organic acids, ammonia, hydrogen sulphide, and metabolites from transformations of other compounds present in the sewage sludge. During anaer-

Table 1 - Components of biogas ${ }^{1-19}$
Table 2 -Methane yield recorded from anaerobic digestion of solid organic waste ${ }^{30}$

\begin{tabular}{lc}
\hline \multicolumn{1}{c|}{ Substrate } & $\begin{array}{c}\text { Methane production, } \\
\mathrm{L} \mathrm{kg}^{-1} \mathrm{TS}\end{array}$ \\
\hline Municipal solid waste & 360 \\
Fruit and vegetable wastes & 420 \\
Municipal solid waste & 530 \\
Fruit and vegetable waste, and abattoir & 850 \\
wastewater & 337 \\
Swine manure & 200 \\
Municipal solid waste & 294 \\
Food waste leachate & 350 \\
Rice straw & 312 \\
Maize silage and straw & 422 \\
Jatropha oil seed cake & 610 \\
Palm oil mill waste & 350 \\
Household waste & 200 \\
Lignin-rich organic waste & 348 \\
Swine manure and winery wastewater & 396 \\
Food waste & \\
\hline
\end{tabular}

obic stabilization, if the toxic substances are presented in quantities not exceeding toxic concentrations, the microorganisms have the adaptive ability and within a certain range of concentration may adapt their enzymatic system to the decomposition. The inhibition of the digestion process under anaerobic conditions may also be caused by reaction changes, temperature fluctuations, and the accidental influx of oxygen. For the proper course of the process, the optimum $\mathrm{pH}$ should be in the range of $7.2-8.2$, and temperature changes should be not greater than $2{ }^{\circ} \mathrm{C}^{5-8}$.

The co-digestion process uses mainly the municipal sewage sludge with the addition of industrial sewage sludge. The following substrates can be mentioned as: fats and greases ${ }^{15,24}$, distillery waste ${ }^{25}$, agricultural vegetable and animal production waste $^{26,27}$, and organic fraction of municipal waste ${ }^{28,29}$. Table 2 shows the output of biogas during the co-digestion of various substrates.

The aim of the study was to determine the possibility of neutralization of coke sewage sludge during anaerobic digestion of municipal sewage sludge. The effect of industrial sewage sludge on the biogas production and gaining of thermal energy was calculated. The effect of co-substrates on the digestion process was assessed based on the degradation of organic compounds and methane production. 


\section{Experimental procedure}

\section{Anaerobic digestion process}

In the study, the sewage sludge coming from municipal sewage treatment plant and the sewage sludge from coking powerplant were used. In the municipal sewage treatment plant, the treatment of waste is carried out in the process of dephosphatation, denitrification, and nitrification. The stabilization of sewage sludge is performed in isolated fermentation chambers in anaerobic conditions. The mixture of thickened sewage sludge is introduced into fermentation chambers. This mixture consists of primary sewage sludge and sludge mixed excessively in volumetric ratio of $4: 1$. Samples were taken of the primary sewage sludge, excess sewage sludge, and the fermented sewage sludge. Samples of the primary sewage sludge and excess sewage sludge were taken from the primary and secondary settle tanks, respectively. Samples of fermented sewage sludge were taken from the fermentation chamber. In the coking wastewater treatment plant, the sewage treatment is performed by the processes of denitrification and nitrification. The sewage flows through a gravel filter, tar separator, and desorption column before it is fed into the biological part of the treatment plant and directed to the averaging tank. Samples of sewage sludge from the coke power plant were taken from the industrial treatment plant (recycled sewage sludge tank). The samples were collected as temporary.

Anaerobic digestion was conducted in glass bioreactors fitted with nozzles for measurement of biogas pressure. The following mixtures were prepared for the digestion studies:

- Municipal sewage sludge (mixture of primary sewage sludge and excess sewage sludge with the addition of fermented sewage sludge as an inoculum) - control sample (K);

- Municipal sewage sludge amended with coking sewage sludge $(20: 1 \mathrm{v} / \mathrm{v})$ - sample A.

The sewage sludge mixtures were incubated for 16 days with no access to light in a thermostat at a constant temperature of $37 \pm 2{ }^{\circ} \mathrm{C}$. The digestion process was carried out in glass reactors with a volume of $1 \mathrm{~L}$ with a single power supply. The volume of sewage sludge was $0.7 \mathrm{~L}$. The process was carried out in 6 reactors with the same mixture of sewage sludge.

\section{Analytical methodology}

In order to determine the flow of the digestion process, the selected physicochemical properties of the sewage sludge were determined. Total solids ( $\left.\mathrm{L} \mathrm{g}^{-1} \mathrm{TS}\right)$, fixed solids ( $\left.\mathrm{L} \mathrm{g}^{-1} \mathrm{FS}\right)$, and hydration (\%) of the sewage sludge before and after 16 days of incubation were analyzed. In the supernatants: $\mathrm{pH}$, alkalinity $\left(\mathrm{g} \mathrm{L}^{-1} \mathrm{CaCO}_{3}\right)$, chemical oxygen demand (CODdiss; $\mathrm{g} \mathrm{L}^{-1} \mathrm{O}_{2}$ ), ammonium nitrogen $\left(\mathrm{g} \mathrm{L}^{-1}\right.$ $\mathrm{N}-\mathrm{NH}_{4}^{+}$) and volatile fatty acids (VFA; $\mathrm{g} \mathrm{L}^{-1}$ $\mathrm{CH}_{3} \mathrm{COOH}$ ) were determined. The analyses were carried out before the digestion process and after $4,8,12$ and 16 days of sample incubation.

\section{Methodology of biogas and methane}

While the process was conducted, the atmospheric pressure and biogas pressure using a manometer in 24-hour intervals were monitored. The daily biogas volume using the Boyle-Mariott equation (11) was calculated. The methane and carbon dioxide contents in biogas were determined four times.

$$
p_{\mathrm{A}} \cdot V_{\mathrm{A}}=p_{\mathrm{B}} \cdot V_{\mathrm{B}}
$$

where:

$p_{\mathrm{A}}-$ pressure in bioreactor, $p_{\mathrm{B}}-$ atmospheric pressure, $\mathrm{hPa}$, respectively

$V_{\mathrm{A}}$ - volume of free space in bioreactor, $V_{\mathrm{B}}-$ biogas volume, $\mathrm{L}$, respectively.

The analysis of biogas composition was conducted using gas chromatography with thermal-conduction detector (GC-TCD) (model Agillent GC 6890). The following temperature program was chosen for the analysis: initial $-50{ }^{\circ} \mathrm{C}$, feeder at $100{ }^{\circ} \mathrm{C}$, detector temperature $250{ }^{\circ} \mathrm{C}$. Nitrogen was used as the carrier gas. The chromatograph was calibrated by injection of $100 \mu \mathrm{L}$ of the standard mixture with purity of: $\mathrm{CO}-99.9 \%, \mathrm{CO}_{2}-99.99 \%$, $\mathrm{O}_{2}-99.997 \%, \mathrm{H}_{2}-99.95 \%, \mathrm{CH}_{4}-99.9 \%$. The standard gaseous mixture consisting of $\mathrm{CO}-0.5 \%$, $\mathrm{CO}_{2}-28.0 \%, \mathrm{O}_{2}-1.0 \%, \mathrm{H}_{2}-0.5 \%, \mathrm{CH}_{4}-70 \%$ was used. $100 \mu \mathrm{L}$ of the tested gas was injected every time in order to determine the content of methane and carbon dioxide in the biogas.

\section{Thermal energy gain}

The energy balance based on the example of the municipal sewage treatment plant, where PE (population equivalent) is higher than $-200,000$ taking into account our own results and the technical data from the sewage treatment plant was calculat$\mathrm{ed}^{31}$.

The daily methane production $Q_{\mathrm{CH}_{4}}\left(\mathrm{~m}^{3} \mathrm{~d}^{-1}\right)$ according to the equation (12) was calculated:

$$
Q_{\mathrm{CH}_{4}}=M \cdot L
$$

where:

$M$ - methane production, $\mathrm{m}^{3} \mathrm{~kg}^{-1} \mathrm{VS}$

$L-$ load of organic matter in the reactor, $\mathrm{kg} \mathrm{VS} \mathrm{d}^{-1}$. 
The theoretical amount of heat energy $Q_{\mathrm{C}}$ $\left(\mathrm{MJ} \mathrm{d}^{-1}\right)$ which can be obtained in the combustion of methane using equation (13) was calculated:

$$
Q_{\mathrm{C}}=Q_{\mathrm{CH}_{4}} \cdot Q_{\mathrm{O}}
$$

where:

$Q_{\mathrm{O}}$ - heat of methane combustion, $\mathrm{MJ} \mathrm{m}^{-3}, Q_{\mathrm{O}}=$ $35.8 \mathrm{MJ} \mathrm{m}^{-3}$.

The required amount of thermal energy $Q_{\mathrm{p}}$ $\left(\mathrm{MJ} \mathrm{d}^{-1}\right)$ to anaerobic digestion process of sewage sludge (heating, mixing sludge) using equation (14) were calculated:

$$
Q_{\mathrm{P}}=V_{o s} \cdot\left(t_{f}-t_{o s}\right) \cdot c_{w}
$$

where:

$V_{o s}$ - sewage sludge volume, $\mathrm{m}^{3} \mathrm{~d}^{-1}$

$t_{f}$ - temperature of sewage sludge during anaerobic digestion process, $\mathrm{K}\left(37^{\circ} \mathrm{C}\right)$

$t_{o s}$ - sewage sludge temperature in winter $t_{o s}=10^{\circ} \mathrm{C}$ $c_{w}$ - specific heat of sewage sludge $c_{w}=4.2 \mathrm{MJ} \mathrm{m}^{-3} \mathrm{~K}^{-1}$.

The amount of heat energy $Q_{\mathrm{s}}\left(\mathrm{MJ} \mathrm{d}^{-1}\right)$ consumed to heat the walls of the fermentation chamber using equation (15) were calculated:

$$
Q_{\mathrm{S}}=24 \cdot\left(t_{f}-t_{z}\right) \cdot k \cdot F
$$

where:

$t_{z}$ - external air temperature, $\mathrm{K}$ (temperature of external air in winter $t_{z}=-20{ }^{\circ} \mathrm{C}$ )

$k$ - coefficient of heat loss as a result of heat of walls of fermentation chambers $\mathrm{MJ} \mathrm{m} \mathrm{m}^{-2} \mathrm{~h}^{-1} \mathrm{~K}^{-1}$, $\left(0.004 \mathrm{MJ} \mathrm{m}^{-2} \mathrm{~h}^{-1} \mathrm{~K}^{-1}\right)$

$F$-surface of walls of fermentation chambers, $\mathrm{m}^{2}$.

The amount of thermal energy $Q_{\mathrm{E}}\left(\mathrm{MJ} \mathrm{d}^{-1}\right)$ using equation (16) was determined:

$$
Q_{\mathrm{E}}=\beta \cdot\left(Q_{P}+Q_{S}\right)
$$

where:

$\beta$ - coefficient of reserve ratio, $\beta=1.1$.

The thermal energy gain $Z(\%)$ according to equation (17) is calculated:

$$
Z=\frac{Q_{\mathrm{C}}-Q_{\mathrm{E}}}{Q_{\mathrm{E}}} \cdot 100 \%
$$

\section{Kinetics of methane production}

Kinetics of methane production based on the total amount of methane production using the equation of first-order reaction (18) is described ${ }^{32}$ :

$$
V=V_{\max } \cdot\left(1-e^{-k t}\right)
$$

where:

$V$ - total methane production in relation to time $t, \mathrm{~L} \mathrm{~L}^{-1}$
$V_{\max }$ - maximum (theoretical) total methane production, $\mathrm{L} \mathrm{L}^{-1}$

$k$ - constant rate coefficient, $\mathrm{d}^{-1}$

$t$ - anaerobic digestion time, $\mathrm{d}$.

Both values of the rate constant and maximum methane production using the method of nonlinear estimation were calculated.

\section{Statistical test}

For the statistical evaluation of the results for the addition of coke sewage sludge to the degradation of organic compounds and biogas production, the t-Student $\left(t_{\mathrm{d}}\right)$ test was used (eq. 19). The number of samples was 5 . The level of confidence was accepted at 0.95 levels. The number specifying the degree of freedom was 2 , for this parameter, and the theoretical value of decomposition of the t-Student $t_{\mathrm{d}}$ was 4.303 .

$$
t_{\mathrm{d}}=\frac{|\bar{d}| \sqrt{\mathrm{n}}}{\frac{\mathrm{n} \sum d^{2}-\left(\sum d\right)^{2}}{\mathrm{n}(\mathrm{n}-1)}}
$$

where:

$\mathrm{n}$ - number of results

$x_{\mathrm{i}}, y_{\mathrm{i}}$ - values of parameters before and after the studies, respectively

$\bar{d}-$ average of value $d, d=x_{\mathrm{i}}-y_{\mathrm{i}}$.

\section{Results and discussion}

\section{Control of anaerobic digestion process}

The mixture of primary sludge and excess sludge by alkalinity of $1.45 \mathrm{~g} \mathrm{~L}^{-1}$ was characterized. The alkalinity in the sewage sludge precipitated during the treatment of coke sewage sludge was equal to $1.20 \mathrm{~g} \mathrm{~L}^{-1}$, while the concentration of ammonia nitrogen amounted to $0.32 \mathrm{~g} \mathrm{~L}^{-1}$. The content of dry matter was equal to $11.26 \mathrm{~g} \mathrm{~L}^{-1}$, and the percentage fraction of the organic substance was $65 \%$. The content of solid residue and organic substance was equal to 19.30 and $14.50 \mathrm{~g} \mathrm{~L}^{-1}$, respectively. The content of solid residue in the fermented sewage sludge was $9.88 \mathrm{~g} \mathrm{~L}^{-1}$. The percentage content of organic substance was $58 \%$.

The results of the physicochemical analysis of the sewage sludge made before the process and after 16 days of stabilization are shown in Table 3. The municipal sewage sludge $(\mathrm{K})$ showed a $20 \%$ decrease in the content of solid residue, while the fraction of organic substance in the fermented sewage sludge was $54 \%$. The content of solid residue was equal to $18.81 \mathrm{~g} \mathrm{~L}^{-1}$ in the municipal sewage 
Table 3 -Changes in the physicochemical properties of sewage sludge during anaerobic digestion process

\begin{tabular}{l|c|c|c|c|c}
\hline \multirow{2}{*}{\multicolumn{1}{c}{ Ratio }} & \multirow{2}{*}{ Unit } & \multicolumn{4}{c}{ Values of digestion } \\
\cline { 3 - 6 } & & \multicolumn{2}{|c}{$\mathrm{K}$} & \multicolumn{2}{c}{$\mathrm{A}$} \\
\cline { 3 - 6 } & & 0 day & 16 day & 0 day & 16 day \\
\hline Total solids & $\mathrm{g} \mathrm{L}^{-1}$ & 18.86 & 15.01 & 18.81 & 14.91 \\
Fixed solids & $\mathrm{g} \mathrm{L}^{-1}$ & 7.46 & 6.83 & 7.72 & 7.03 \\
Volatile solids & $\mathrm{g} \mathrm{L}^{-1}$ & 11.40 & 8.18 & 11.09 & 7.88 \\
Hydration & $\%$ & 98.13 & 98.49 & 98.11 & 98.52 \\
\hline
\end{tabular}

sludge amended with industrial sewage sludge. After the process of co-digestion, the content of solid residue decreased to $21 \%$. The percentage fraction of organic substance in the fermented sewage sludge was equal to $53 \%$ for sludge $\mathrm{A}$. The rate of decomposition of organic substance was similar in all samples: $28.9 \%$ in the mixture of sewage sludge A, and $28.2 \%$ in the control sludge $(\mathrm{K})$.

The changes in concentration of VFA, alkalinity, CODdiss, ammonia nitrogen and $\mathrm{pH}$ observed during the tests are shown in Figs. 1 and 2, respectively. The post anaerobic digestion alkalinity determined in supernatants was within $3.50-3.55 \mathrm{~g} \mathrm{~L}^{-1}$ in all samples.

The ratio of volatile fatty acids to alkalinity decreased in proportion to the duration of the process, and its value in the control sludge after the process was 0.11 . In the mixture of municipal sewage sludge and coking sewage sludge, the value of the quotient of VFA to alkalinity had not exceeded 0.09 . The content of organic compounds determined as CODdiss in supernatants separated from municipal sludge (K) was reduced by $88 \%$. The reduction inorganic compounds in mixture A expressed by the CODdiss index was $81 \%$. The equal $\mathrm{pH}$ was noted during the study, between 7.7 and 7.8 after stabilization of reactor operation. The concentration of ammonia nitrogen after digestion process in the sewage sludge was in the range of $0.31-0.33 \mathrm{~g} \mathrm{~L}^{-1}$.

\section{Biogas production}

The volumes of biogas formed during digestion process are shown in Fig. 3. For the municipal sewage sludge $(\mathrm{K})$, the highest production of biogas was achieved on the third day $\left(1.4 \mathrm{~L} \mathrm{~L}^{-1}\right)$, while for the sludge mixture on the fourth day $\left(1.1 \mathrm{~L} \mathrm{~L}^{-1}\right)$. This may have indicated a temporary inhibition of lag-phase in the digestion process by coke sewage sludge. The total biogas production in samples A and $\mathrm{K}$ was $10.6\left(0.56 \mathrm{~L} \mathrm{~g}^{-1} \mathrm{TS}\right)$ and $11.7 \mathrm{~L} \mathrm{~L}^{-1}(0.62$ $\mathrm{L} \mathrm{g}^{-1} \mathrm{TS}$ ), respectively. The percentage of methane content in the biogas varied from 61 to $69 \%$.

According to the literature data, during sewage sludge anaerobic digestion, the alkalinity should be from 3.00 to $5.00 \mathrm{~g} \mathrm{~L}^{-1}$, and VFA concentration from 0.05 to $0.50 \mathrm{~g} \mathrm{~L}^{-1}, \mathrm{pH}$ should be from 7.2 to 8.2 , and CODdiss reduction should be $65-85 \%{ }^{33,34}$.

In the study conducted by Grosser et al., the co-digestion of municipal sewage sludge and vegetable fat waste from the fatty acid methyl ester production plant was studied. It could be concluded that the addition of waste to municipal sewage sludge in the co-digestion process had a negative effect on the efficiency of the process: the biogas production was lower by $50 \%$, the level of organic compounds decomposition was lower by $16.5 \%{ }^{24}$.

In the study conducted by Dąbrowska, the total biogas production during 14-day anaerobic stabilization of the sewage sludge was $6.9 \mathrm{~L} \mathrm{~L}^{-1}$ and the methane content ranged between $61-70 \%$. The anaerobic digestion rate of the sewage sludge was $33 \%$ and the fraction of organic substance in the digested sewage sludge was $59 \%{ }^{16}$. In other studies, the total biogas production after 21 days was $1.9 \mathrm{~L}^{22}$. In the study conducted by Luostarinen, $\mathrm{pH}$ was in the range of 7.1-7.7, the concentration of volatile fatty acids varied from 0.09 to $0.11 \mathrm{~g} \mathrm{~L}^{-111}$. In other studies, after the anaerobic digestion of sewage sludge, the content of volatile fatty acids

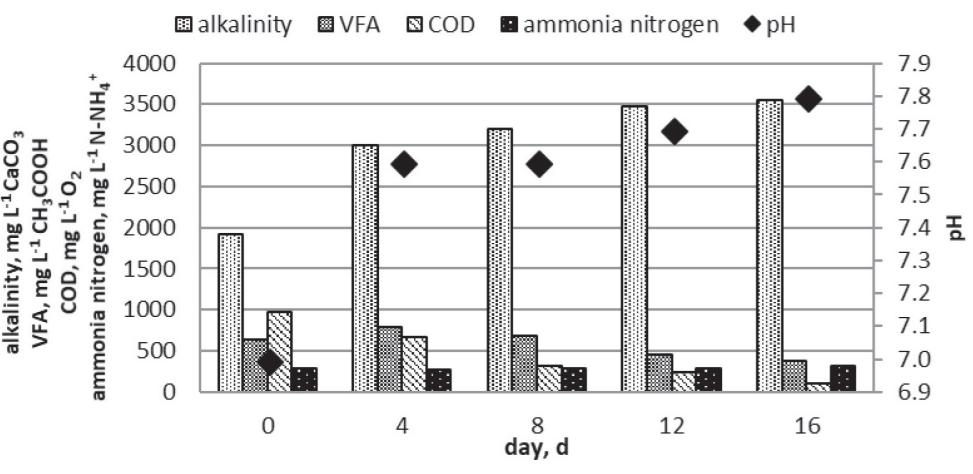

Fig. 1 - Changes in the concentration of VFA, alkalinity, CODdiss, ammonia nitrogen, and $\mathrm{pH}$ in municipal sludge during anaerobic digestion (mixture $K$ )

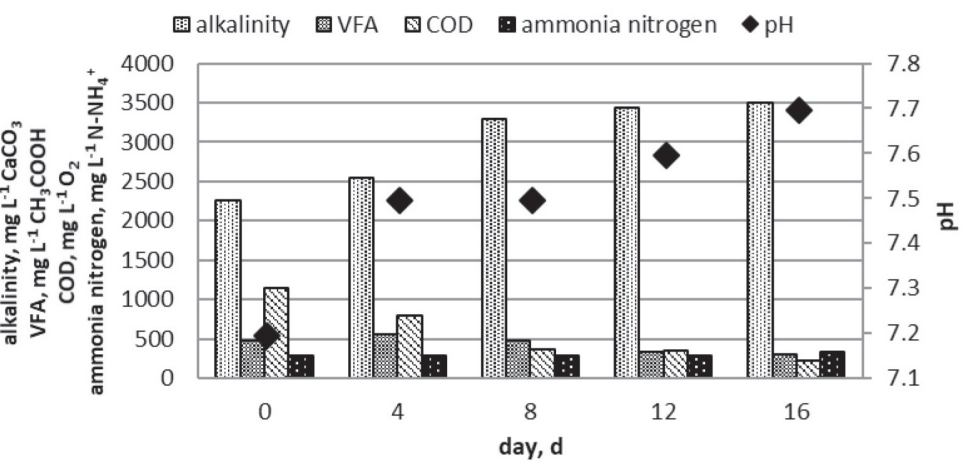

Fig. 2 - Changes in the concentration of VFA, alkalinity, CODdiss, ammonia nitrogen, and $\mathrm{pH}$ in the mixture of municipal sludge with coke sewage sludge during co-digestion (mixture A) 


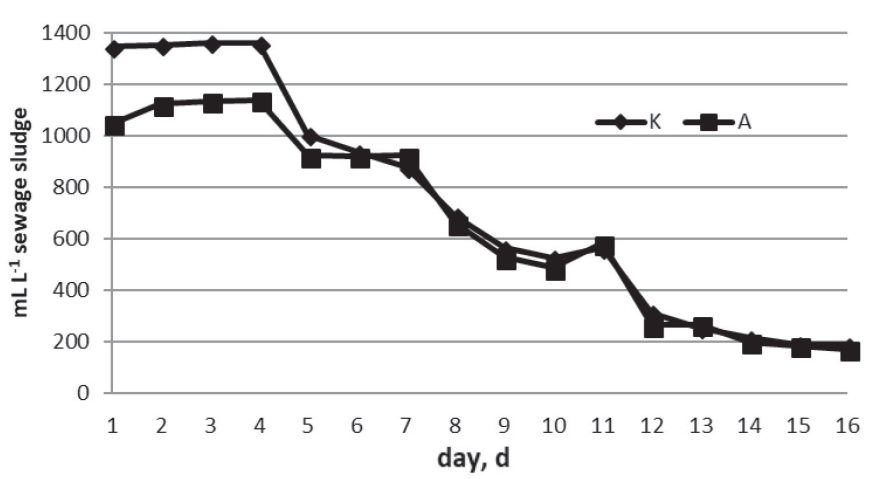

Fig. 3 - Volume of biogas produced during anaerobic digestion process

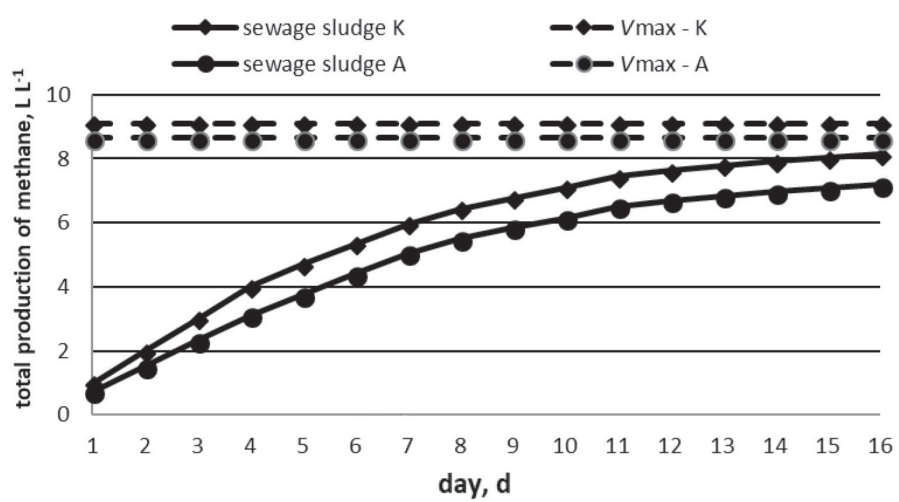

Fig. 4 - Volume of methane during anaerobic digestion process

was $0.65 \mathrm{~g} \mathrm{~L}^{-1}$, the quotient of VFA and alkalinity was 0.1 . The value of $\mathrm{pH}$ was 7.2 , and the loss of solid residue amounted to $52 \%$. The authors investigated the process of co-digestion of sewage sludge amended with fats using various volume ratios. During the co-digestion of sewage sludge with fats (20\% and $40 \%$ ), the VFA concentration was 0.66 and $0.71 \mathrm{~g} \mathrm{~L}^{-1}$, respectively. The $\mathrm{pH}$ was 7.2 , and the methane content in biogas amounted to $66 \%$ and $70 \%$, respectively ${ }^{14}$.

The total methane production in the sludge mixture $\mathrm{K}$ and $\mathrm{A}$ is shown in Fig. 4. The amount of methane $\left(8.1 \mathrm{~L} \mathrm{~L}^{-1}\right)$ was achieved from control sewage sludge $(\mathrm{K})$, whereas $12 \%$ less methane was achieved from the sewage sludge mixture $\mathrm{A}\left(7.2 \mathrm{~L} \mathrm{~L}^{-1}\right)$. It could have been due to the persistent compounds present in the coke sewage sludge.

The values of selected parameters of co-digestion of the municipal sewage sludge and coking sludge are presented in Table 4. The initial load of organic compounds in the digestion chambers was $0.5 \mathrm{~g} \mathrm{VS} \mathrm{L}^{-1} \mathrm{~d}^{-1}$ on average. During the anaerobic digestion of sewage sludge mixtures, the difference between the maximal value methane production $\left(V_{\max }\right)$ and the real value methane production was determined. This value corresponded to the theoretical amount of the biogas that might have produced
Table 4 -Parameters of co-digestion process

\begin{tabular}{|c|c|c|c|}
\hline Parameters & Unit & $\mathrm{K}$ & A \\
\hline $\begin{array}{l}\text { Load of organic compounds in the } \\
\text { fermentation chambers }\end{array}$ & $\mathrm{g} \mathrm{VS} \mathrm{L}^{-1} \mathrm{~d}^{-1}$ & 0.55 & 0.47 \\
\hline $\begin{array}{l}\text { Percentage of the organic substance } \\
\text { decomposition }\end{array}$ & $\%$ & 28.2 & 28.9 \\
\hline \multirow{3}{*}{$\begin{array}{l}\text { Production of biogas during } \\
\text { digestion process }\end{array}$} & $\mathrm{L} \mathrm{L}^{-1}$ & 11.7 & 10.6 \\
\hline & $\mathrm{L} \mathrm{g}^{-1} \mathrm{TS}$ & 0.62 & 0.56 \\
\hline & $\mathrm{L} \mathrm{g}^{-1} \mathrm{VS}$ & 1.03 & 0.95 \\
\hline $\begin{array}{l}\text { Content of methane in biogas on } \\
\text { average }\end{array}$ & $\%$ & 61 & 69 \\
\hline \multirow{3}{*}{$\begin{array}{l}\text { Production of methane during } \\
\text { digestion process }\end{array}$} & $\mathrm{L} \mathrm{L}^{-1}$ & 8.1 & 7.2 \\
\hline & $\mathrm{L} \mathrm{g}^{-1} \mathrm{TS}$ & 0.43 & 0.38 \\
\hline & $\mathrm{L} \mathrm{g}^{-1} \mathrm{VS}$ & 0.71 & 0.65 \\
\hline \multirow{3}{*}{$\begin{array}{l}\text { Maximal (theoretical) methane } \\
\text { production }\left(V_{\max }\right)\end{array}$} & $\mathrm{L} \mathrm{L}^{-1}$ & 9.1 & 8.7 \\
\hline & $\mathrm{L} \mathrm{g}^{-1} \mathrm{TS}$ & 0.48 & 0.46 \\
\hline & $\mathrm{L} \mathrm{g}^{-1} \mathrm{VS}$ & 0.80 & 0.78 \\
\hline $\begin{array}{l}\text { Potential of methane remaining in } \\
\text { sewage sludge }\end{array}$ & $\%$ & 10 & 17 \\
\hline $\begin{array}{l}\text { Constant rate of the methane } \\
\text { production, } k\end{array}$ & $\mathrm{~d}^{-1}$ & 0.147 & 0.119 \\
\hline Nonlinear estimation error & $\mathrm{L} \mathrm{L}^{-1}$ & 0.14 & 0.17 \\
\hline Coefficient of determination, $R^{2}$ & - & 0.995 & 0.989 \\
\hline
\end{tabular}

in the sludge and varied in the range of $1.0-1.5 \mathrm{~L} \mathrm{~L}^{-1}$. The percentage of disused methane during the anaerobic digestion process of sewage sludge was in the range of $10 \%-17 \%$. In the study by Montusiewicz, the disused biogas in sewage sludge anaerobic digestion process varied from 11.6 to $14.1 \%{ }^{31}$

During the anaerobic digestion process of municipal sewage sludge and coking sludge mixture, the constant rate of methane production was in the range of $0.119-0.147 \mathrm{~d}^{-1}$. In the study conducted by Myszograj, the constant rates of methane production during the digestion process of the sewage sludge varied from 0.179 to $0.203 \mathrm{~d}^{-1}$ and during the digestion process of biofraction of municipal waste it varied from 0.077 to $0.137 \mathrm{~d}^{-113}$.

\section{Energy balance of methane}

Table 5 shows the value of energy balance during anaerobic digestion process of municipal sewage sludge and during co-digestion process of sewage sludge amended with coking sewage sludge.

According to the calculations, the thermal energy gain was achieved in the process of digestion for municipal sewage sludge $\mathrm{K}$ as well as for the sewage sludge mixture A. The biogas produced is suffi- 
Table 5 - Energy balance of the digestion process

\begin{tabular}{lccccc}
\hline \multicolumn{1}{c|}{ Parameters } & Abbreviation & Unit & $\mathrm{K}$ & $\mathrm{A}$ \\
\hline $\begin{array}{l}\text { Volume of methane } \\
\text { production }\end{array}$ & $Q_{\mathrm{CH}_{4}}$ & $\mathrm{~m}^{3} \mathrm{~d}^{-1}$ & 3477 & 3443 \\
$\begin{array}{l}\text { Theoretical amount of } \\
\text { thermal energy }\end{array}$ & $Q_{\mathrm{C}}$ & $\mathrm{MJ} \mathrm{d}^{-1}$ & 124477 & 123275 \\
$\begin{array}{l}\text { Required energy } \\
\text { (process heat) for } \\
\text { heating and mixing of } \\
\text { sewage sludge in the } \\
\text { fermentation chamber }\end{array}$ & $Q_{\mathrm{P}}$ & $\mathrm{MJ} \mathrm{d}^{-1}$ & 52500 \\
$\begin{array}{l}\text { Loss of thermal } \\
\text { energy }\end{array}$ & $Q_{\mathrm{S}}$ & $\mathrm{MJ} \mathrm{d}^{-1}$ & 15064 \\
$\begin{array}{l}\text { Total requirement of } \\
\text { thermal energy }\end{array}$ & $Q_{\mathrm{E}}$ & $\mathrm{MJ} \mathrm{d}^{-1}$ & 74320 \\
\hline \begin{tabular}{l} 
Thermal energy gain \\
\hline
\end{tabular} & $Z$ & $\%$ & 40 & 40 \\
\hline
\end{tabular}

cient for heating the fermentation chamber. The excess energy can be applied for other purposes in the sewage treatment plants. During the anaerobic digestion of sewage sludge $\mathrm{K}$ and sewage sludge mixture A, $40 \%$ excess of methane was obtained. The results correspond to the study conducted by Montusiewicz, in which the thermal energy gain during anaerobic digestion of sewage sludge was in the range of $34 \%-39.5 \%^{31}$.

\section{Statistical calculations}

The addition of coking sludge to municipal sewage sludge had no significant effect on the process parameters, such as total biogas production, organic substance decomposition rate, changes in content of organic compounds expressed by CODdiss index, loss of solid residue, and methane content in biogas $\left(t_{\mathrm{d}}<4.303\right)$.

Due to the loss of organic compounds, biogas production, fraction of organic substance in fermented sewage sludge and thermal energy gain, it can be concluded that both the municipal sewage sludge and mixtures with coking sludge were well digested. The results correspond with data provided by other authors.

\section{Conclusions}

Based on the conducted study it can be stated:

- It is possible to neutralize the coke sewage sludge during anaerobic digestion of municipal sewage sludge for the mixture 20:1.

- The anaerobic digestion of municipal sewage sludge amended with coking sewage sludge $(20: 1 \mathrm{v} / \mathrm{v})$ had no statistically important effect on the decomposition of organic compounds.
- During the anaerobic digestion process, the thermal energy gain of $40 \%$ of methane was achieved.

- During the anaerobic digestion process of sewage sludge, the biogas volume was $0.59 \mathrm{~L} \mathrm{~g}^{-1} \mathrm{TS}$ on average.

- Coke excess sewage sludge can be neutralized in digestion along with municipal sewage sludge providing constant quality-quantitative control of sewage sludge and procedural parameters. However, in order to confirm the above, it is necessary to conduct the study in a flow system.

\section{References}

1. Bartkiewicz, B., Treatment of industrial wastewater, Pol. Sci. Publishers PWN, Warsaw, 2008, pp 88-108 (in polish).

2. Macherzyński, B., Włodarczyk-Makuła, M., Nowacka, A., Simplification of the procedure of preparing samples for PAHs and PCBs determination, Arch. Environ. Prot. 38 (2012) 23

doi: https://doi.org/10.2478/v10265-012-0037-1

3. Macherzyński, B., Włodarczyk-Makuła, M., Nowacka, A., Desorption of PAHs from solid phase into liquid phase during co-digestion of municipal and coke sewage sludge, Desalin. Water Treat. 52 (2014) 3859. doi: https://doi.org/10.1080/19443994.2014.887450

4. Jin, X., Li, E., Lu, S., Qiu, Z., Sui, Q., Coking wastewater treatment for industrial reuse purpose: Combining biological processes with ultrafiltration, nanofiltration and reverse osmosis, J. Environ. Sci. 25 (2013) 1565. doi: https://doi.org/10.1016/S1001-0742(12)60212-5

5. Sadecka, Z., Weiss, E., Myszograj, S., Processing of sewage sludge with energy recovery in a wastewater treatment plant, Environ. Prot. Eng. 38 (2012) 97.

6. Kalderis, D., Aivalioti, M., Gidarakos, E., Options for sustainable sewage sludge management in small wastewater treatment plants on islands: The case of Crete, Desalination 260 (2010) 211

doi: https://doi.org/10.1016/j.desal.2010.04.030

7. Nges, I., Liu, J., Effects of solid retention time on anaerobic digestion of dewatered-sewage sludge in mesophilic and thermophilic conditions, Renewable Energy 35 (2010) 2200 .

doi: https://doi.org/10.1016/j.renene.2010.02.022

8. Siuris, A., Properties of sewage sludge resulted from urban wastewater treatment in the Republic of Moldova, Sci. Pap. UASVM Bucharest, Ser. A. 54 (2011) 103.

9. Alrawi, R., Ahmad, A., Ismail, N., Kadir, M., Anaerobic co-digestion of palm oil mill effluent with rumen fluid as a co-substrate, Desalination 269 (2011) 50-57. doi: https://doi.org/10.1016/j.desal.2010.10.041

10. Pawłowska, M., Siepak, J., Enhancement of methanogenesis at a municipal landfill site by addition of sewage sludge, Environ. Eng. Sci. 23 (2006) 673. doi: https://doi.org/10.1089/ees.2006.23.673

11. Luostarinen, S., Luste, S., Sillanpää, M., Increased biogas production at wastewater treatment plants through co-digestion of sewage sludge with grease trap sludge from a meat processing plant, Bioresour. Technol. 100 (2009) 79. doi: https://doi.org/10.1016/j.biortech.2008.06.029 
12. Davidsson, Ĺ., Lövstedt, C., Jansen, J., Gruvberger, C., Aspergen, $H$., Co-digestion of grease trap sludge and sewage sludge, Waste Manage. 28 (2008) 986. doi: https://doi.org/10.1016/j.wasman.2007.03.024

13. Myszograj, S., Biochemical methane potential as indicator of biodegradability of organic matter in anaerobic digestion process, Rocz. Ochr. Sr. 13 (2011) 1245.

14. Noutsopoulos, C., Mamais, D., Antoniou, K., Avramides, C., Oikonomopoulos, P., Fountoulakis, I., Anaerobic co-digestion of grease sludge and sewage sludge: The effect of organic loading and grease sludge content, Bioresour. Technol. 131 (2013) 452. doi: https://doi.org/10.1016/j.biortech.2012.12.193

15. Carrere, H., Rafrafi, Y., Battimelli, A., Torrijos, M., Delgenes, J. P., Motte, C., Improving methane production during the digestion of waste-activated sludge and fatty wastewater: Impact of thermo-alkaline pretreatment on batch and semi-continuous processes, Chem. Eng. J. 210 (2012) 404 doi: https://doi.org/10.1016/j.cej.2012.09.005

16. Dabrowska, L., Fermentation of sewage sludge with increased concentration of heavy metal ions, Inżynieria Ekologiczna 25 (2011) 67.

17. Silvestre, G., Rodríguez-Abalde, A., Fernández, B., Flotats, $X$., Bonmatí, A., Biomass adaptation over anaerobic co-digestion of sewage sludge and trapped grease waste, Bioresour. Technol. 102 (2011) 6830. doi: https://doi.org/10.1016/j.biortech.2011.04.019

18. Arthur, R., Brew-Hammond, A., Potential biogas production from sewage sludge: A case study of the sewage treatment plant at Kwame Nkrumah University of Science and Technology, Ghana, Int. J. Energy Environ. 6 (2010) 1009.

19. Ali Shah, F., Mahmood, Q., Maroof Shah, M., Pervez, A., Ahmad Asad, S., Microbial ecology of anaerobic digesters: The key players of anaerobiosis, Sci. World J. 2014 (2014). doi: https://doi.org/10.1155/2014/183752

20. Demirel, B., Scherer, P., The roles of acetotrophic and hydrogenotrophic methanogens turning anaerobic conversion of biomass to methane: A review, Rev. Environ. Sci. Bio/ Technol. 7 (2008) 173.

doi: https://doi.org/10.1007/s11157-008-9131-1

21. Szymański, K., New solutions in biogas production according to MT-ENERGIE® technology, Rocz. Ochr. Sr. 12 (2010) 249.

22. Sadecka, Z., Impact of pyrethroids on methane digestion, Civ. Environ. Eng. Rep. 2 (2007) 59.

23. Chen, Y., Cheng, J. J., Creamer, K. S., Inhibition of anaerobic digestion process: A review, Bioresour. Technol. 99 (2008) 4044. doi: https://doi.org/10.1016/j.biortech.2007.01.057
24. Grosser, A., Worwag, M., Neczaj, E., Grobelak, A., Semi-continuous anaerobic co-digestion of mixed sewage sludge and waste fats of vegetable origin, Rocz. Ochr. Sr. 15 (2013) 2108.

25. Babel, S., Sae-Tang, J., Pecharaply, A., Anaerobic co-digestion of sewage and brewery sludge for biogas production and land application, Int. J. Environ. Sci. Technol. 6 (2009) 131. doi: https://doi.org/10.1007/BF03326067

26. Gomez, X., Cuetos, M. J., Cara, J., Moran, A., Garcia, A. I., Anaerobic co-digestion of primary sludge and the fruit and vegetable fraction of the municipal solid wastes: Conditions for mixing and evaluation of the organic loading rate, Renewable Energy 31 (2006) 2017. doi: https://doi.org/10.1016/j.renene.2005.09.029

27. Angelidaki, I., Ellegaard, L., Codigestion of manure and organic wastes in centralized biogas plants, Appl. Biochem. Biotechnol. 109 (2003) 95. doi: https://doi.org/10.1385/ABAB:109:1-3:95

28. Esposito, G., Frunzo, L., Giordano, A., Liotta, F., Panico, A., Pirozzi, F., Anaerobic co-digestion of organic wastes, Rev. Environ. Sci. Bio/Technol. 11(2012) 325. doi: https://doi.org/10.1007/s11157-012-9277-8

29. Sosnowski, P., Klepacz-Smolka, A., Kaczorek, K., Ledakowicz, $S$., Kinetic investigations of methane co-fermentation of sewage sludge and organic fraction of municipal solid wastes, Bioresour. Technol. 99 (2008) 5731. doi: https://doi.org/10.1016/j.biortech.2007.10.019

30. Khalid, A., Arshad, M., Anjum, M., Mahmood, T., Dawson, $L$., The anaerobic digestion of solid organic waste, Waste Manage. 31 (2011) 1737. doi: https://doi.org/10.1016/j.wasman.2011.03.021

31. Montusiewicz, A., Współfermentacja osadów ściekowych i wybranych kosubstratów jako metoda efektywnej biometanizacji, Vol. 98, Pol. Acad. Sci., Inst. Environ. Eng., Comm. Environ. Eng. Lublin, 2012 (in polish).

32. Budiyono, I., Sumardiono, S., Kinetic model of biogas yield production from vinasse at various initial $\mathrm{pH}$ : Comparison between modified Gompertz model and first order kinetic model, Res. J. Appl. Sci., Eng. Technol. 7 (2014) 2798 doi: https://doi.org/10.19026/rjaset.7.602

33. Kardos, L., Juhasz, A., Palko, G. Y., Olah, J., Barkacs, K., Zaray, G. Y., Comparing of mesophilic and thermophilic anaerobic fermented sewage sludge based on chemical and biochemical tests, Appl. Ecol. Environ. Sci. 9 (2011) 293. doi: https://doi.org/10.15666/aeer/0903_293302

34. Álvarez, A. A., Otero, L., Lema, J. M., A methodology for optimising feed composition for anaerobic co-digestion of agro-industrial wastes, Bioresour. Technol. 101 (2010) 1153. doi: https://doi.org/10.1016/j.biortech.2009.09.061 